\title{
Apparent density, trypanosome infection rates and host preference of tsetse flies in the sleeping sickness endemic focus of Northwestern Uganda
}

Robert Opiro ( $\sim$ robopiro@gu.ac.ug )

Gulu University Faculty of Science https://orcid.org/0000-0003-4246-9336

Robert Opoke

Muni University

Harriet Angwech

Gulu University Faculty of Science

Esther Nakafu

Makerere University

Francis A. Oloya

Gulu University

Geoffrey Openy

Gulu University

Moses Njahira

International Livestock Research Institute

Mercy Macharia

International Livestock Research Institute

Richard Echodu

Gulu University

Geoffrey M. Malinga

Gulu University

Elizabeth A. Opiyo

Gulu University Faculty of Science

Research article

Keywords: C01, Cytb, nested PCR, reservoir hosts, mixed infection, Adjumani, Moyo

Posted Date: November 16th, 2020

DOl: https://doi.org/10.21203/rs.3.rs-43888/v3 
License: (c) (i) This work is licensed under a Creative Commons Attribution 4.0 International License. Read Full License 


\section{Abstract}

Background: African trypanosomiasis, caused by protozoa of the genus Trypanosoma and transmitted by the tsetse fly, is a serious parasitic disease of humans and animals. Reliable data on the vector distribution, feeding preference and the trypanosome species they carry is pertinent to planning sustainable control strategies.

Methodology: We deployed 109 biconical traps in 10 villages in two districts of northwestern Uganda to obtain information on the apparent density, trypanosome infection rates and blood meal sources of tsetse flies. A subset (272) of the collected samples was analyzed for detection of trypanosomes species and sub-species using a nested PCR protocol based on primers amplifying the Internal Transcribed Spacer (ITS) region of ribosomal DNA. 34 blood-engorged adult tsetse midguts were analyzed for blood meal sources by sequencing of the mitochondrial cytochrome c oxidase 1 (COI) and cytochrome b (cytb) genes.

Results: Out of the 109 traps deployed, we captured 622 Glossina fuscipes fuscipes tsetse flies (269 males and 353 females). Apparent density (AD) ranged from 0.6 to 3.7 flies/trap/day in the two districts. $29(10.7 \%)$ of the flies were infected with one or more trypanosome species. Infection rate was not significantly associated with neither age group $\left(x^{2}=5.001, d f=2,0.082\right)$, sex of the fly $\left(x^{2}=0.099, d f=1, p\right.$ $=0.753)$, district of origin $\left(\chi^{2}=0.629, d f=1, p=0.428\right)$ nor village $\left(\chi^{2}=9.252, d f=9, p=0.414\right)$. Nested PCR revealed several species of trypanosomes: T. vivax (6.62\%), T. congolense (2.57\%), T. brucei and $T$. simiae each at $0.73 \%$. Blood meal analyses revealed five principal vertebrate hosts, namely, cattle (Bos taurus), humans (Homo sapiens), Nile monitor lizard (Varanus niloticus), African mud turtle (Pelusio schapini) and the African Savanna elephant (Loxodonta africana).

Conclusion: We found an infection rate of $10.78 \%$, with all infections attributed to trypanosome species that are causative agents for the animal disease only. However, more verification of this finding using large-scale passive and active screening of human and tsetse samples should be done. Cattle and humans appear to be the most important tsetse hosts in the region and should be considered in the design of interventions.

\section{Background}

African trypanosomes, members of the genus Trypanosoma, are flagellated parasitic protozoa that cause zoonotic diseases generally known as African trypanosomiasis. The diseases are known as sleeping sickness (or human African trypanosomiasis, HAT) and Nagana (or animal African trypanosomiasis, AAT) and are inextricably linked in humans and livestock, respectively. HAT still remains one of the most devastating neglected tropical diseases of poverty that causes severe morbidity and mortality, with over 70 million people at risk of being infected in Sub-Saharan Africa [1]. AAT on the other hand is a major constraint to livestock production causing massive economic burden in sub-Saharan Africa. The Food and Agricultural Organization of the United Nations (FAO) estimates that Africa loses up to US\$1.5 billion annually as a result of the disease [2]. Thus, these diseases together, have both negative health and economic impacts. 
In Uganda, vector-borne diseases, notably AAT presents a major constraint to livestock productivity [3,4]. Poor livestock health as a result of AAT denies farmers draught power and manure thereby contributing to poverty and hunger in the tsetse-infested areas $[5,6]$. Regarding HAT, despite the current small number of cases, Uganda is the only country where both the chronic (caused by T. b. gambiense) and acute (caused by $T$. b. rhodesiense) forms of the disease occur. The T. b. gambiense form occurs in the northwestern corner of the country (where this study was conducted) while T. b. rhodesiense is in the Eastern and Southern part of Uganda. Evidence already point to a danger of merger of the two HAT belts, fueled by animal movements [7,8], and vector migration northwards [9-11]. This underscores the need for research geared towards providing information to support sustainable control in the country.

\section{Methods}

\section{Study sites and sample collection}

The study was carried out in Adjumani $\left(3.3784^{\circ} \mathrm{N}, 31.7822^{\circ} \mathrm{E}\right)$ and Moyo districts $\left(3.6527^{\circ} \mathrm{N}, 31.7281^{\circ} \mathrm{E}\right)$ in northwestern Uganda (Fig. 1). Northwestern Uganda has traditionally been known as an endemic sleeping sickness focus but just like in the rest of the continent, there has been a gradual decline in the number of new cases. For example, passive screening conducted in 2014, detected just nine cases in the region [15], and in 2018, out of the 10,000 individuals screened, none was infected with T. b. gambiense [16]. In the same year, a tsetse control intervention was expanded to cover the main gambiense HAT foci in West Nile to curtail transmission of gambiense, and this reduced the prevalence to below the elimination threshold ( 1 new case per 10,000 population), making elimination on course across this study area if status is maintained [16]. Regarding AAT, there are numerous confirmed and anecdotal reports of the presence of the disease among cattle keeping households. Moreover, a recent study [17] found the prevalence of $T$. b.brucei in local cattle, pigs and tsetse flies are as follows, $1.9 \%, 6.3 \%$ and $1.8 \%$, respectively. Therefore, AAT still remains a public health challenge in the region.

The region has rainfall periods that run from March-May and from July-November, with a short dry spell in June and a fairly long period of dryness from December to February. The vegetation is a mixture of forests and savannah, with open woodland, grassland, and shrubs.. Besides, there are several fast running streams passing through subsistence farms with low plains and rolling hills and valleys that slope towards the river Nile. The typical riverine habitats are suitable for Glossina fuscipes fuscipes, the principal tsetse vector in this area. The population is largely rural, practicing mixed crop and livestock farming, consisting of food and cash crops such as tobacco, and livestock, mainly cattle, goats, sheep and pigs.

Tsetse trapping was conducted using biconical traps [18] baited with acetone and cow urine, deployed along suitable habitats, targeting majorly areas of human and animal activities (Fig. 2). At each site, an average of 10 traps were mounted approximately $100 \mathrm{~m}$ apart in different vegetation types for three consecutive days and in well shaded areas to minimize fly mortality due to excessive heat. The traps were deployed in the villages of Olwi, Olobo, Oringya, Osugo East and Pagirinya in Adjumani district, and in 
Orubakulem, Ori, Lea, Cefo and Moyipi villages in Moyo district. The geographical coordinate of each trap was recorded using a handheld Global Positioning Systems (GPS) unit (GPS 12 XL, Garmin Ltd. 2003, Olathe, Kansas, USA). We also recorded the trap codes, sex of the captured flies and dates of collection. To prevent the attack of ants on the flies in the traps, each supporting pole was smeared with grease.

Trapped tsetse flies were collected every 24 hours for at least three consecutive days [19] . After each collection, tsetse flies were identified morphologically, counted and sorted into teneral and non-teneral as described by Laveissière et al. [20]. The tsetse flies were assigned to one of the six age categories, according to the degree of wear or fraying observed on the hind margin of the wing as described by Jackson [21]. After categorizing the wing fray (WF), the actual age of the fly was estimated using directions for estimating the mean age of a sample of tsetse flies as outlined in the FAO Training manual for tsetse control personnel [22]. The ages of tsetse flies based on wing fray categories were later pooled as "young tsetse" (WF1-2), "old tsetse" (WF 3-4) and "very old tsetse" (WF 5-6) for statistical analysis. Only fresh and non-teneral flies were then selected for dissection to obtain midguts, salivary glands and proboscis. The teneral flies were excluded from the analyses. The dissections were carried out as described in the FAO Training Manual for Tsetse Control Personnel [22]. Trapped flies were dissected in phosphate buffered saline in $2 \%$ glucose under a dissecting microscope. Samples of midguts, salivary glands and proboscis from dissected flies were preserved in $70 \%$ ethanol in sealed eppendorf tubes until required for subsequent DNA extraction and PCR assays.

\section{DNA extraction}

The ethanol preserved tissues (miguts, proboscis and salivary glands) of each tsetse sample was pooled together in a single tube and genomic DNA extracted using Purelink ${ }^{T M}$ extraction kit from Invitrogen following the manufacturer's instructions. The supernatant was used either directly for PCR or stored at $-20^{\circ} \mathrm{C}$. Prior to their use or storage, DNA samples were electrophoresed in a $1 \%$ agarose gel in $0.5 \times \mathrm{TBE}$ buffer at $100 \mathrm{~V}$ for 45 mins. The quality of DNA in the sample was then estimated by comparing florescent yield of the sample with standard cut Lambda DNA run alongside the DNA samples.

\section{Identification of different trypanosome species}

To detect trypanosome DNA, we employed the nested PCR protocol described by Cox et al., [23], using the same primer sequences but with slight modifications in amplification conditions. The outer primer sequences were ITS1 (5-GAT TAC GTC CCT GCCATT TG-3), and ITS2 (5-TTG TTC GCT ATC GGTCTT CC-3) and inner primer sequences ITS3 (5-GGA AGC AAA AGT CGT AACAAG G-3), and ITS4 (5-TGT TTT CTT TTC CTCCGC TG-3). PCR amplifications were performed in two rounds. The first round was performed in a final reaction volume of $20 \mu \mathrm{L}$ containing $10 \mathrm{pmol}$ of each primer, the BioneerAccuPower ${ }^{\circledR}$ PCR premix (Bioneer Corporation), and $2 \mu \mathrm{L}$ of each DNA template. The amplification conditions began with 1 cycle of denaturation at $95^{\circ} \mathrm{C}$ for $5 \mathrm{~min}$ followed by 40 amplification cycles at $94^{\circ} \mathrm{C}$ for $1 \mathrm{~min}, 55^{\circ} \mathrm{C}$ for $1 \mathrm{~min}$, and $72{ }^{\circ} \mathrm{C}$ for 2 minutes. In the second round, $2 \mu \mathrm{L}$ of the amplified product from the first round was placed in a fresh tube and $20 \mu \mathrm{L}$ of the reaction mixture was added as described above for the outer primers, except that the outer primers (ITS1 and 2) were substituted with the inner primers (ITS3 and 4). The 
amplifications conditions were identical to the one described for the first PCR round. To minimize bias due to false positives during repeated PCRs, negative controls in which DNA templates were replaced with sterile distilled water as well as positive control DNAs (of each trypanosome species) were included in all PCR reactions. All reactions were carried out using a GeneAmp 9700 thermal cycler PCR system (Applied Biosystems). After the nested PCR, $5 \mu \mathrm{L}$ of the amplified products were loaded on a casted $1.8 \%$ agarose gel, which was subsequently stained with a Gel Red nucleic acid stain, with a 75bp gene marker. These were run in a Mupid ${ }^{\circledR}$-exu Sub-marine electrophoresis gel tank (Helix Technologies Inc. MEXO 0800137) for 45 mins at $100 \mathrm{~V}$ in $0.5 \mathrm{X}$ TBE buffer. The gels were then visualized under ultra-violet illumination and photographed. Trypanosomes species and subspecies were identified by comparing the molecular sizes of their DNA fragments with the documented band sizes of trypanosome species [23] (Table 1). For $T$. brucei, further investigation was done by running a second PCR for diagnosis of $T$. b. gambiense employing a nested-PCR with a first reaction using TgsGP1/2 primers [24] and a second one with TgsGP sense2/antisense2 primers described by Morrison et al. [25].

\section{Identification of tsetse blood meal sources}

To test for the origin of blood meals, samples of DNA from residual blood meal in tsetse midguts were amplified using PCR with universal primers complementary to the conserved region of mitochondrial DNA (mtDNA) $\mathrm{CO} 1$ and cytb gene as detailed by Muturi et al., [26]. The primer sequences for the $\mathrm{C01}$ gene was VF1d_t1 (5' TGTAAAACGACGGCCAGTTCTCAACCAACCACAARGAYATYGG- 3') and VR1d_t1 (5'CAGGAAACAGCTATGACTAGACTTCTGGGTGGCCRAARAAYCA- $3^{\prime}$ ) and for the Cyt b was (Cb5'CCATCCAACATCTCAGCATGATGAAA-3') and (Cb2 5'-CCCCTCAGAATGATATTTGTCCTCA-3') as described by Ivanova et al., [27] and Kocher et al., [28], respectively. Both PCR reactions were performed in a total volume of $20 \mu \mathrm{l}$ containing $10 \mathrm{pmol}$ of each primer, $10 \mathrm{mMTris}-\mathrm{Cl}, \mathrm{pH} 8.3$ and $50 \mathrm{mMKCl}, 1.5 \mathrm{mM} \mathrm{MgCl}$, 2.5 mMdNTPs, $2 \mu \mathrm{L}$ of the DNA template and 1 unit DreamTaq ${ }^{\text {TM }}$ DNA polymerase (Fermentas Life Sciences). The PCR was then carried out in a GeneAmpPCR System 9700 (Applied Biosystems) thermocycler. The conditions for C01 PCR were as follows: initial denaturation at $94^{\circ} \mathrm{C}$ for 5 minutes, followed by 45 cycles of denaturation at $94^{\circ} \mathrm{C}$ for $30 \mathrm{~s}$, annealing at $55^{\circ} \mathrm{C}$ for 1 minute, and primer extension at $72^{\circ} \mathrm{C}$ for 30 seconds. For Cyt b PCR, conditions were: initial denaturation at $94^{\circ} \mathrm{C}$ for 5 minutes, followed by 40 cycles of denaturation at $94^{\circ} \mathrm{C}$ for $45 \mathrm{~s}$, annealing at $55^{\circ} \mathrm{C}$ for $45 \mathrm{sec}$, and primer extension at $72^{\circ} \mathrm{C}$ for $30 \mathrm{~s}$. Positive and negative controls were included in each PCR assay. The positive controls were cattle genomic DNA obtained from the Animal Health Unit at ILRI Research Laboratories. Negative controls consisted of the Master Mix for each PCR and fresh Milli Q water obtained from the Central Core of the BeCA hub laboratories. To analyze the amplicons, $5 \mu \mathrm{L}$ of the PCR product, as well as negative and positive controls, was resolved in a 1.8\% agarose gel at 80 volts for 45 minutes and visualised under UV transilluminator following gel red staining. The amplified products were visualized under ultra-violet illumination and a picture of the gel taken using the gel documentation and analysis systems mounted with a high-performance CCD Camera-COHU.

The PCR products were gel-purified using the GeneJet ${ }^{\mathrm{TM}}$ kit (catalog no K0702 EU) following the manufacturer's instructions and submitted to the BeCA-ILRI Hub Sequencing Unit (Segolip) for sequencing 
using Bigdye ${ }^{T M}$ Terminator. Sequencing was done bi-directionally using the inner amplification primers for the $\mathrm{CO} 1$ and $c y t b$ genes. Consensus sequences were then generated by contiguation functions of the CLC Main Workbench Version 6.6.2 and manually edited, where necessary, by reference to the chromatograms. Vertebrate species were confirmed by sequence alignments with those already deposited in GenBank database using the Basic Local Alignment Search Tool (BLAST, https://blast.ncbi.nIm.nih.gov/Blast.cgi) [29]. Sequences of a given pair-wise alignment from positive PCR products with high percentage similarity (identity matches of $90-98 \%$ ) and lowest E-values were selected as the most likely species of host.

\section{Data analyses}

The average Apparent density (AD), expressed as the average number of flies caught per trap per day (flies/ trap/ day or FTD), was calculated to obtain the data on tsetse distribution in the area for each trapping site using the formula: $F T D=\Sigma F / T \times D$, where, $\Sigma F$ is the total number of tsetse flies caught, $T$ is the number of traps deployed and $D$ is the number of days of trapping in the field. Tsetse infection rates were calculated by dividing the number of flies infected with trypanosomes by the total number of flies analysed, and expressed as percentages. Pearson chi-square goodness of-fit-tests $\left(\chi^{2}\right)$ were employed to determine the association of tsetse infection rates with fly's sex, district of origin, and age based on wing fray categories. Values of $p$-value $<0.05$ were considered significant at $95 \%$ confidence interval $(\mathrm{Cl})$. Independent samples t-test was conducted to compare whether the average number of flies caught per trap per day differed between the two districts under study. All statistical tests were performed using SPSS software (version 21.0.1, SPSS Inc., Chicago, IL, USA).

\section{Results}

\section{Entomological survey}

We caught 622 tsetse flies (269 males and 353 females) (Table 2) from 109 traps deployed in 10 villages (five in each district). Of these, 320 flies were caught from Adjumani and 302 from Moyo districts, respectively. All the tsetse flies caught belonged to the Glossina fuscipes fuscipes species. Apparent density (AD) ranged from 0.58 to 3.67 tsetse flies per trap per day for all villages. However, the average FTD in the two districts did not differ significantly (Independent samples t-test, $t=0.35, d f=8, p=0.458$ ). The average age of flies caught in Adjumani district was 30 days (Mean Wing Fray Value, MWFV = 3.8) while for Moyo district was 25 days old (MWFV = 3.3) (Table 2).

\section{Molecular identification of trypanosomes species and sub-speciess}

We analyzed $43 \%(272 / 622)$ of the collected tsetse samples for detection of trypanosomes. Out of the 29 infected tsetse flies found in both districts, Trypanosoma vivax was the most prevalent species accounting for $6.62 \%(18 / 272)$ of the infections, followed by $T$. congolense (all three sub types Kilifi, Forest and Savanna; $2.57 \%(7 / 272)$, and T. brucei and T. simiae each at $0.74 \%(2 / 272)$ (Table 3). The results of investigation for $T$. brucei gambiense turned out negative, and since we did not expect the other Trypanozoon (T. evansi and T. b rhodesiense) to be present in this geographical area, we concluded that 
the subspecies was T. brucei brucei. There were two cases of mixed infections with $T$. brucei brucei/T. vivax. The overall prevalence of the different species and sub-species in the two districts is shown in Figure 3.

\section{Trypanosome infection rates}

The overall infection rate was $10.67 \%$ (29/272). Trypanosome infection was not significantly associated with sex $\left(x^{2}=0.099, d f=1, p=0.753\right)$ and age based on wing fray category $\left(x^{2}=5.001, d f=2,0.082\right)$. Furthermore, the trypanosome infection rate also showed no association with district $\left(\chi^{2}=0.629, d f=1, p\right.$ $=0.428)$ and village $\left(x^{2}=9.252, d f=9, p=0.414\right)$. In Adjumani district, the village with the highest infection rates was Olobo 18.3\% (11/60), followed by Oringya $14.2 \%(2 / 14)$, Osugo East $11.4 \%(4 / 35)$ and Pagirinya 3.45\%(1/29). In Moyo District, the highest infection rates were recorded in Orubakulem $11.67 \%$ $(7 / 60)$, followed by $10 \%(3 / 30)$ and then Ori $6.25 \%(1 / 16)$. There was no infected fly in Cefo and Moyipi villages (Table 3).

\section{Blood meal identification}

A total of 34 blood-engorged flies' midgut samples was analyzed to determine the sources of the blood meal. Amplification of the COI and Cyt b genes all gave a $650 \mathrm{bp}$ and 359bp PCR products, respectively, on $1.8 \%$ agarose gels (Fig. 4).

Hosts were identified in $88.2 \%$ (30/34) analyzed samples, with sequence identities ranging from $96-100 \%$ in homology with reference sequences in Genbank. The four unidentified samples consistently amplified tsetse DNA, implying probably degraded blood meal DNA. Tsetse hosts identified included cattle (14/30), Humans (8/30), Nile monitor lizard (5/30), African mud turtle (2/30) and the African savanna elephant $(1 / 30)$ (Table 4).

\section{Discussion}

This study assessed tsetse fly populations in Adjumani and Moyo Districts in northwestern Uganda, a known African trypanosomiasis endemic focus. The only species of tsetse caught was Glossina fuscipes fuscipes. This is probably because of the nature of our sampling scheme that mainly targeted the edges of major rivers and streams as well as peri-domestic environments. Glossina fuscipes fuscipes is known to generally disperse along waterways, following riverbeds or the edges of gallery forests, where they are able to survive low humidity conditions during dry seasons [30-32]. Female flies were consistently higher than males in most traps in both Adjumani and Moyo Districts. This finding is similar to results of a survey in Mukono district, southeastern Uganda where the percentage of females was higher than that of males in all study months [33]. The high percentage of females than males caught by our traps could be due to the fact that there may have simply been more females than males in the study area, and thus our catches was representative of the sex ratio in the population [34]. Females are also known to be more prolific feeders; male flies feed every 3-4 days [35]whereas females take blood meals regularly due to their role in reproduction [36], which increases their chances of getting trapped as they seek for blood meals. 
In the present work, we found no significant difference in apparent density between the two districts implying that the similarity in biotopes present favorable habitats for tsetse in both districts. The average AD obtained in this study is similar to the findings by Azabo et al. [37] in mid northern Uganda. However, it's lower than those reported in southeastern Uganda by Waiswa et al. [38]. This observed difference could be attributed to variations in the environmental and agro-ecological conditions and the season in the study areas. Northern and northwestern Uganda differ significantly in climate, especially in annual precipitation, from the southern part of the country [39]. Southern Uganda has a somewhat cooler climate and is less humid, with mean annual rainfall near Lake Victoria often exceeding $2100-3000 \mathrm{~mm}$; the high temperature varies by $2-3^{\circ} \mathrm{C}$ over the year, with a mean daily high being around $26^{\circ} \mathrm{C}$. In the north and northwest, the rainfall is between 1000 and $2000 \mathrm{~mm}$, and temperature varies by $5{ }^{\circ} \mathrm{C}$ over the year, with the mean daily high being $29^{\circ} \mathrm{C}$ [40]. The presence of unique climatic background creates different tsetse population dynamics, and may be responsible for the observed difference in AD.

Our results showed that $10.7 \%$ of tsetse flies in both Adjumani and Moyo Districts were infected by at least one trypanosome species. This figure is relatively high given that infection rates are known to be generally low in tsetse flies [41]. Other studies in Uganda have reported lower rates; Azabo et al. [37] got an infection rate of $5.6 \%$ in tsetse flies from mid northern Uganda districts of Lira, Apac and Kole. Waiswa et al. [42] got an even lower rate (1.55\%) in southeastern Uganda, although their study was based on microscopic examination only. However, the infection rate reported in this study is lower than those reported from other studies in Sub-Saharan Africa such as Simo et al., [43] who reported $19.3 \%$ at the Malanga sleeping sickness foci in the Democratic Republic of Congo and Simo et al. [44] who reported $25.5 \%$ in Cameroon. Our comparatively higher infection rates than reported elsewhere in Uganda can be explained by the fact that livestock owners in Adjumani and Moyo Districts are not keen on use of trypanocidal drugs due to high costs associated with purchase (District Veterinary Officer, Adjumani, Personal Communication, July, 2018).

Our results indicated that sex of fly had no significant association with trypanosome infection. This contrast with the suggestion that fly sex appears to influence susceptibility to trypanosome infection [4548]. Females are also known to live longer than males [49], and infected female tsetse that live longer could increase the number of infected females compared to male flies. Moreover, the presence of high number of females caught in this study might result in high population and probably high infection rate [50]. However, there have been instances where higher number of infections was associated with male flies $[45,46,48]$. Thus, the precise associations of trypanosome infection with sex remain unresolved. Trypanosome infection rates were also not correlated with age, contrary to the suggestion that older flies have higher risk of infection than their younger counterparts. This could be due to the relatively small sample size analysed in this study.

The most common trypanosome species in tsetse flies in the two districts was $T$. vivax, accounting for $67 \%$ of the infected flies. Magona et al. [51] found similar results in studies of Glossina fuscipes fuscipes tsetse flies in Southeast Uganda. In this study, our traps caught only Glossina fuscipes fuscipes, which known to be more susceptible to T. vivax infections [52]. Trypanosoma vivax is also known to have a 
shorter developmental life cycle and can be mechanically transmitted by haematopahgous insects, which may explain its predominance in the surveyed samples [53]. An earlier study by Angwech et al. [54] in Amuru and Nwoya districts, which border the study area in the present study, found that $T$. vivax was also the most predominant trypanosome species in cattle. Our results are also consistent with several other previous studies on tsetse and trypanosomes ecology in Uganda [38,42,55].

Our analyses did not find human infective trypanosome species in the tsetse samples analysed. A recent epidemiological survey in the neighbouring Arua and Koboko districts, all of which are within the same gambiense focus, also reported no cases of sleeping sickness in the region [17]. It is possible therefore that the transmission of $T$. b. gambiense has been decisively suppressed and prevalence reduced to near elimination. The driver behind this unprecedented decline has probably been the large active and passive screening programme by the Ugandan National Sleeping Sickness Programme and Medecins Sans Frontières (MSF) France between 1987 and 2002 [56], and vector control using tiny targets that reduced tsetse numbers by more than $90 \%$ [56]. In West Nile, the last large-scale active screening was undertaken by MSF Spain and the Ministry of Health (MoH) supported by WHO in 2010 and 2011 [16]. However, more extensive screening in the vectors is paramount given our relatively small sample size, since it's known that the prevalence of gambiense HAT disease amongst wild tsetse populations is often extremely low [57-59].

In the present study, we used two genetic markers (COI and cytb) for identification of tsetse blood meal sources in Adjumani and Moyo. The $\mathrm{COI}$ gene has a higher taxonomic coverage in reference databases [60] but $C y t b$ has been shown to be better than $\mathrm{COI}$ at detection of the origin of digested blood meals in some insect vectors [61]. Muturi et al., [26] consistently failed to amplify tsetse vertebrate host DNA from Glossina swynnertoni using the COI gene for flies caught in the Serengeti. However, by complementing the analyses of the $\mathrm{COI}$ gene with the analyses of $C y t b$, the authors were able to identify blood meal sources of the caught tsetse. Conversely, in the study of Petterson et al., [62], the authors used COI for blood meal analyses for samples that did not produce results with $C y t b$ primers in order to increase the opportunity for host identification. Therefore, where possible, the use of both markers for detection of blood meal sources in vertebrates is a logical application since the $\mathrm{COI}$ and $C y t b$ DNA barcoding regions from more species are being sequenced and submitted to public databases.

Sequence analyses showed various blood meal sources, with cattle and humans being the predominant hosts. Glossina fuscipes fuscipes is known to be a non-preferential feeder, with blood meals taken from the most available hosts [63]. However, in Adjumani and Moyo districts, tsetse mostly feed on humans and cattle due to the fact that the environment is highly anthropized and wild animals are rare, except in Zoka forest, which has abundant wildlife [64], an area we did not sample. Another probable reason for the high cases of blood meal from cattle, and to some extent humans, is that this survey was done in the dry season when it is common that animals, especially cattle, are taken to the banks of rivers and streams to graze and drink water. As such, Glossina fuscipes fuscipes, a riverine species, gain access to the cattle and humans who attend to the animals and utilize the water for domestic and other uses. There was, however, one curious case of a blood meal taken from an elephant. This particular fly was trapped from 
Arinyapi sub-county in Adjumani district, which borders southern Sudan. Trans-boundary elephants especially from Nimule National Park in South Sudan that have on several occasions destroyed numerous acres of food crops belonging to hundreds of small-scale farmers in the two sub-counties of Arinyapi and Dzaipi [65] are seemingly potential hosts of Glossina tsetse in the study area. Results of blood meal analyses furthermore highlight the importance of reptiles, especially monitor lizards and African mud turtles, as important hosts for Glossina fuscipes fuscipes tsetse. Previous studies in southeastern Uganda $[42,63,66]$ and on the shores of Lake Victoria in Kenya [67] identified monitor lizards as an important food source for tsetse. It has been proposed that the preference for reptiles may simply reflect an ecological 'concordance' between flies and lizards; both are cold-blooded and probably with similar diurnal pattern in the environment where they co-exist [67]. Reptiles are even suspected to be natural cryptic reservoirs of human infective trypanosomes [68].

\section{Conclusion}

The present study has shown an infection rate of $10.78 \%$, with all infections attributed to trypanosome species that are causative agents of the animal disease only. However, the absence of detection of human infective trypanosomes in tsetse flies in this endemic focus require verification using large-scale passive and active seasonal entomological and human screening to ascertain if HAT is not anymore a public health problem in the study area. Finally, this study reveals that cattle and humans are among the most important blood meal sources for tsetse flies in the region and should be considered in the design of tsetse and trypanosomiasis control interventions.

\section{Declarations}

\section{Acknowledgements}

The authors are highly indebted to the MSI Diagnostics Project at Gulu University, and the African Biosciences Challenge Fund Fellowship for financial and logistical support. We also wish to acknowledge the Biosciences Eastern and Central Africa (BecA)-ILRIHub, Nairobi for providing laboratory space and allowing us to use their facilities for molecular analysis of the samples. Management of Gulu University is also highly acknowledged for granting R01 leave to undertake laboratory work at the BecA-ILRI Hub laboratories in Nairobi, Kenya. Thanks also go to the technicians (Mr. Okello Alfonse and Mr. Khizza Constant), and to the District Entomologists and the District Veterinary Officers of Adjumani and Moyo districts for assistance with fieldwork.

\section{Authors' contributions}

R01, RE and EAO conceived and designed the study. RO1, AH, MN, and MM collected data and performed the lab analyses. R01, RO2 performed initial analyses and wrote initial draft of manuscript. GMM, EN, RE, EAO, FAO, AH and GO critically revised the manuscript. All authors read and approved the final version of the manuscript. 


\section{Funding}

This study was supported financially by the Gulu University MSI Trypanosome Diagnostics Project (Project no: MSI/WAI/3/29/2010) and by the African Biosciences Challenge Fund Fellowship (ABCF) award to R01. The funders had no role in study design, data collection and analysis, decision to publish, or preparation of the manuscript.

\section{Availability of data and materials}

The data supporting the conclusion of this study is available from the link: https://osf.io/jhtu3/quickfiles

\section{Ethics approval and consent to participate}

This research was approved by the Gulu University Institutional Review Board and by the Uganda National Council for Science and Technology.

\section{Consent for publication}

Not applicable.

\section{Competing interests}

The authors declare that they have no competing interests.

\section{Authors' details}

${ }^{1}$ Department of Biology, Faculty of Science, Gulu University, P.O Box 166, Gulu, Uganda. ${ }^{2}$ Department of Biology, Faculty of Science, Muni University, P.O Box 725, Arua, Uganda. ${ }^{3}$ Department of Biosystems Engineering, Faculty of Agriculture and Environment, Gulu University, P. O Box 166, Gulu, Uganda.

${ }^{4}$ Biosciences Eastern and Central Africa-International Livestock Research Institute Hub, P. O Box 30709, Nairobi, Kenya. ${ }^{5}$ Department of Molecular Biology, College of Veterinary Medicine, Animal Resources and Biosecurity, Makerere University, P.O Box 7062, Kampala, Uganda. ${ }^{6}$ Department of Biology, University of Eastern Finland, P. O. Box 11180101 Joensuu, Finland.

\section{Abbreviations}

AD: Apparent Density; COI: Cytochrome Oxidase l; FAO: Food and Agricultural Organization; HAT: Human African Trypanosomiasis; AAT: Animal African Trypanosomiasis; OD: Optical Density; PCR: Polymerase Chain Reaction; TgsGP: Trypanosoma gambiense specific Glycoprotein; WHO: World Health Organization

\section{References}

1. Franco, J. R., Cecchi, G., Priotto, G., Paone, M., Diarra, A., Grout, L., ... \& Argaw D(. Monitoring the elimination of human African trypanosomiasis: update to 2014. PLoS neglected Trop Dis. 2017;11: 
e0005585.

2. WHO. WHO Fact Sheet [Internet]. 2017. Available: https://www.who.int/news-room/factsheets/detail/diarrhoeal-disease

3. Okello WO, Muhanguzi D, MacLeod ET, Welburn SC, Waiswa C, Shaw AP. Contribution of draft cattle to rural livelihoods in a district of southeastern Uganda endemic for bovine parasitic diseases: an economic evaluation. Parasit Vectors. Springer; 2015;8: 571.

4. Muhanguzi D, Okello WO, Kabasa JD, Waiswa C, Welburn SC, Shaw APM. Cost analysis of options for management of African Animal Trypanosomiasis using interventions targeted at cattle in Tororo District; south-eastern Uganda. Parasit Vectors. Springer; 2015;8: 387.

5. Murray M GA. The current situation on animal trypanosomiasis in Africa. Prev Vet Med. 1984;2: 2330.

6. Swallow B: Impacts of African animal trypanosomosis on migration, livestock and crop production. Nairobi, ILRI. 1998; 1-19.

7. Fèvre, E.M., Coleman, P.G., Odiit, M., Magona, J.W., Welburn, S.C. \& Woolhouse MEJ. The origins of a new Trypanosoma brucei rhodesiense sleeping sickness outbreak in eastern Uganda. Lancet. 2001;358: 625-28.

8. Selby, R., Bardosh, K., Picozzi, K., Waiswa, C., and Welburn CS. Cattle movments and trypanosomes: restocking efforts and the spread of Trypanosoma brucei rhodesiense sleeping sickness in postconflict Uganda. Parasit Vectors. 2013;6: 281-303.

9. Opiro, R., Saarman, N. P., Echodu, R., Opiyo, E. A., Dion, K., Halyard, A., ... \& Caccone A. Genetic diversity and population structure of the tsetse fly Glossina fuscipes fuscipes (Diptera: Glossinidae) in Northern Uganda: Implications for vector control. PLoS Negl Trop Dis. 2017;11.

10. Echodu R, Sistrom M, Hyseni C, Enyaru J, Okedi L, Aksoy S, et al. Genetically distinct Glossina fuscipes fuscipes populations in the Lake Kyoga region of Uganda and its relevance for human African trypanosomiasis. Biomed Res Int. 2013;2013: 614721. doi:10.1155/2013/614721

11. Beadell JS, Hyseni C, Abila PP, Azabo R, Enyaru JCK, Ouma JO, et al. Phylogeography and Population Structure of Glossina fuscipes fuscipes in Uganda: Implications for Control of Tsetse. PLoS Negl Trop Dis. 2010;4: e636. doi:10.1371/journal.pntd.0000636

12. Solano P, Kaba D, Ravel S, Dyer N a., Sall B, Vreysen MJB, et al. Population genetics as a tool to select tsetse control strategies: Suppression or eradication of Glossina palpalis gambiensis in the niayes of senegal. PLoS Negl Trop Dis. 2010;4: 1-11. doi:10.1371/journal.pntd.0000692

13. Jordan AM. Trypanosomiasis control and African rural development. London: Longman; 1986.

14. Stich, A. BM and K. Waking up to sleeping sickness. Trends Parasitol. 2003;19: 195-197.

15. WHO. Number of new reported cases (T.b. gambiense) Data by country Geneva: World Health Organisation. 2015; Available: http://apps.who.int/gho/data/node.main.A1636?lang=en

16. Selby R, Wamboga C, Erphas O, Mugenyi A, Jamonneau V, Waiswa C, et al. Gambian human African trypanosomiasis in North West Uganda. Are we on course for the 2020 target? PLoS Negl Trop Dis. Public Library of Science; 2019;13. 
17. Cunningham LJ, Lingley JK, Tirados I, Esterhuizen J, Opiyo M, Mangwiro CTN, et al. Evidence of the absence of human African trypanosomiasis in two northern districts of Uganda: Analyses of cattle, pigs and tsetse flies for the presence of Trypanosoma brucei gambiense. PLoS Negl Trop Dis. Public Library of Science; 2020;14: e0007737.

18. Challier, A and Laveissiere C. A new trap for capturing Glossina flies (Diptera: Muscidae), description and field trials. Cah ORSTOM Entomol Med Parasitol. 1973;11: 251-262.

19. Williams B, Dransfield R BR. Tsetse fly (Diptera: Glossinidae) population dynamics and the estimation of mortality rates from life-table data. Bull Entomol Res. 1990;80: :479-485.

20. Laveissière C, Grébaut P, Herder S PL. Les glossines vectrices de la Trypanosomiase humaine. F. rance Louis-Jean Ed. 2000;

21. Jackson CHN. An artificially isolated generation of tsetse flies (Diptera). Bull Entomol Res. 37: 291.

22. FAO. Training Manual for Tsetse Control Personnel. Food and Agriculture Organisation of the United Nations (FAO). Rome.; 1979.

23. Cox, A., Tilley, A., McOdimba, F., Fyfe, J., Eisler, M., Hide, G., \& Welburn S. A PCR based assay for detection and differentiation of African trypanosome species in blood. Exp Parasitol. 2005;11: 24-29.

24. Radwanska M, Claes F, Magez S, Magnus E, Perez-Morga D, Pays E, et al. Novel primer sequences for polymerase chain reaction-based detection of Trypanosoma brucei gambiense. Am J Trop Med Hyg. ASTMH; 2002;67: 289-295.

25. Morrison LJ, Tait A, McCormack G, Sweeney L, Black A, Truc P, et al. Trypanosoma brucei gambiense Type 1 populations from human patients are clonal and display geographical genetic differentiation. Infect Genet Evol. Elsevier; 2008;8: 847-854.

26. Muturi CN, Ouma JO, Malele II, Ngure RM, Rutto JJ, Mithöfer KM, et al. Tracking the feeding patterns of tsetse flies (Glossina genus) by analysis of bloodmeals using mitochondrial cytochromes genes. PLoS One. Public Library of Science; 2011;6.

27. Ivanova N V, Zemlak TS, Hanner RH, Hebert PDN. Universal primer cocktails for fish DNA barcoding. Mol Ecol Notes. Wiley Online Library; 2007;7: 544-548.

28. Kocher TD, Thomas WK, Meyer A, Edwards S V, Pääbo S, Villablanca FX, et al. Dynamics of mitochondrial DNA evolution in animals: amplification and sequencing with conserved primers. Proc Natl Acad Sci. National Acad Sciences; 1989;86: 6196-6200.

29. Altschul SF, Gish W, Miller W, Myers EW, Lipman DJ. Basic local alignment search tool. J Mol Biol. Elsevier; 1990;215: 403-410.

30. Leak SGA. Tsetse biology and ecology: their role in the epidemiology and control of trypanosomosis. Wallingford.: CAB I Publishing, Wallingford.; 1999.

31. Bouyer J, Guerrini L, César J, De La Rocque S, Cuisance D. A phyto-sociological analysis of the distribution of riverine tsetse flies in Burkina Faso. Med Vet Entomol. Wiley Online Library; 2005;19: 372-378.

32. Opiro R, Saarman NP, Echodu R, Opiyo EA, Dion K, Halyard A. Evidence of temporal stability in allelic and mitochondrial haplotype diversity in populations of Glossina fuscipes fuscipes ( Diptera: 
Glossinidae ) in northern Uganda. Parasit Vectors. Parasites \& Vectors; 2016; 1-12. doi:10.1186/s13071-016-1522-5

33. Katunguka-Rwakishaya E KE. Tsetse survey in Mukono district, south-east Uganda: population structure, distribution and blood meal status. Trop Anim Heal Prod. 1996;28: 151-157.

34. Leak SGA, Ejigu D, Vreysen MJB. Collection of entomological baseline data for tsetse area-wide integrated pest management programmes. Food and Agriculture Organization of the United Nations (FAO); 2008.

35. Davies H. 'Tsetse flies Nigeria.' Ibadan: Oxford University Press, Ibadan.; 1977.

36. Moloo SK. Aspects of the nutrition of adult female Glossina morsitans during pregnancy. J Insect Physiol. Elsevier; 1976;22: 563-567.

37. R Azabo, P Abila, L Odhiambo, C. Waiswa FE and LO. Trypanosome Infection rates in tsetse (Glossina fuscipes fuscipes) in communal grazing lands in Mid-northern Uganda. Online J Vet Res. 2016;20: 225-236.

38. Waiswa C, Picozzi K, Katunguka-Rwakishaya E O-MW, Musoke RA WS. Glossina fuscipes fuscipes in the trypanosomiasis endemic areas of south eastern Uganda: apparent density, trypanosome infection rates and host feeding preferences. Acta Trop. 2003;99: 23-29.

39. Aksoy S, Caccone A, Galvani AP, Okedi LM. Glossina fuscipes populations provide insights for human African trypanosomiasis transmission in Uganda. Trends Parasitol. Elsevier Ltd; 2013;29: 394-406. doi:10.1016/j.pt.2013.06.005

40. Basalirwa CP. Delineation of Uganda into Climatological rainfall zones using the method of principal component analysis. Int J Climatol. 1995;15: 1161-1177.

41. Aksoy S. Control of tsetse flies and trypanosomes using molecular genetics. Vet Parasitol. Elsevier; 2003;115: 125-145.

42. Waiswa C, Picozzi K, Katunguka-Rwakishaya E, Olaho-Mukani W, Musoke RA, Welburn SC. Glossina fuscipes fuscipes in the trypanosomiasis endemic areas of south eastern Uganda: apparent density, trypanosome infection rates and host feeding preferences. Acta Trop. Elsevier; 2006;99: 23-29.

43. Simo G, Silatsa B, Flobert N, Lutumba P, Mansinsa P, Madinga J, et al. Identification of different trypanosome species in the mid-guts of tsetse flies of the Malanga (Kimpese) sleeping sickness focus of the Democratic Republic of Congo. Parasit Vectors. BioMed Central; 2012;5: 1-9.

44. Simo G, Fongho P, Farikou O, Ndjeuto-Tchouli PIN, Tchouomene-Labou J, Njiokou F, et al. Trypanosome infection rates in tsetse flies in the "silent" sleeping sickness focus of Bafia in the Centre Region in Cameroon. Parasit Vectors. Springer; 2015;8: 528.

45. Dale C, Welburn SC, Maudlin I, Milligan PJM. The kinetics of maturation of trypanosome infections in tsetse. Parasitology. Cambridge University Press; 1995;111: 187-191.

46. Maudlin, I., Welburn, S.C., Gashumba, J.K., Okuna, N. and Kalunda M. The role of cattle in the epidemiology of sleeping sickness. Bull la Socie'te' Fr aise Parasitol. 1990;8: 788.

47. Moore S, Shrestha S, Tomlinson KW, Vuong H. Predicting the effect of climate change on African trypanosomiasis: integrating epidemiology with parasite and vector biology. J R Soc Interface. 
2012;9: 817-30. doi:10.1098/rsif.2011.0654

48. Moloo SK, Sabwa CL, Kabata JM. Vector competence of Glossina pallidipes and G. morsitans centralis for Trypanosoma vivax, T. congolense and T. b. brucei. Acta Trop. Elsevier; 1992;51: 271280 .

49. MIHOK S, Munyoki ELI, BRETT RA, JONYO JF, RÖTTCHER D, MAJIWA PAO, et al. Trypanosomiasis and the conservation of black rhinoceros (Diceros bicornis) at the Ngulia Rhino sanctuary, Tsavo West National park, Kenya. Afr J Ecol. Wiley Online Library; 1992;30: 103-115.

50. Desta M, Beyene D, Haile S. Trypanosome infection rate of Glossina pallidipes and trypanosomosis prevalence in cattle in Amaro Special District of Southern Ethiopia. J Vet Med Anim Heal. Academic Journals; 2013;5: 164-170.

51. Magona JW, Walubengo J, Odiit M, Okedi LA, Abila P, Katabazi BK, et al. Implications of the reinvasion of Southeast Uganda by Glossina pallidipes on the epidemiology of bovine trypanosomosis. Vet Parasitol. Elsevier; 2005;128: 1-9.

52. Moloo SK, Kutuza SB, Boreham PFL. Studies on Glossina pallidipes, G. fuscipes fuscipes and G. brevipalpis in terms of the epidemiology and epizootiology of trypanosomiases in south-eastern Uganda. Ann Trop Med Parasitol. Taylor \& Francis; 1980;74: 219-237.

53. Jordan AM. Recent developments in the ecology and methods of control of tsetse flies (Glossina spp.)(Dipt., Glossinidae) -a review. Bull Entomol Res. Cambridge University Press; 1974;63: 361-399.

54. Angwech H, Nyeko JHP, Opiyo EA, Okello-Onen J, Opiro R, Echodu R, et al. Heterogeneity in the prevalence and intensity of bovine trypanosomiasis in the districts of Amuru and Nwoya, Northern Uganda. BMC Vet Res. BioMed Central; 2015;11: 255.

55. Biryomumaisho S, Rwakishaya E-K, Melville SE, Cailleau A, Lubega GW. Livestock trypanosomosis in Uganda: parasite heterogeneity and anaemia status of naturally infected cattle, goats and pigs. Parasitol Res. Springer; 2013;112: 1443-1450.

56. Tirados I, Esterhuizen J, Kovacic V, Mangwiro TNC, Vale GA, Hastings I, et al. Tsetse control and Gambian sleeping sickness; implications for control strategy. PLoS Negl Trop Dis. Public Library of Science; 2015;9: e0003822.

57. Jamonneau V, Ravel S, Koffi M, Kaba D, Zeze DG, Ndri L, et al. Mixed infections of trypanosomes in tsetse and pigs and their epidemiological significance in a sleeping sickness focus of Cote d'Ivoire. Parasitology. Cambridge University Press; 2004;129: 693-702.

58. Farikou O, Njiokou F, Simo G, Asonganyi T, Cuny G, Geiger A. Tsetse fly blood meal modification and trypanosome identification in two sleeping sickness foci in the forest of southern Cameroon. Acta Trop. Elsevier; 2010;116: 81-88.

59. Kagbadouno MS, Camara M, Rouamba J, Rayaisse J-B, Traore IS, Camara O, et al. Epidemiology of sleeping sickness in Boffa (Guinea): where are the trypanosomes? PLoS Negl Trop Dis. Public Library of Science; 2012;6.

60. Porter TM, Hajibabaei M. Over 2.5 million COI sequences in GenBank and growing. PLoS One. Public Library of Science San Francisco, CA USA; 2018;13: e0200177. 
61. Hadj-Henni L, De Meulemeester T, Depaquit J, Noël P, Germain A, Helder R, et al. Comparison of vertebrate cytochrome $b$ and prepronociceptin for blood meal analyses in Culicoides. Front Vet Sci. Frontiers; 2015;2: 15.

62. Pettersson E, Bensch S, Ander M, Chirico J, Sigvald R, Ignell R. Molecular identification of bloodmeals and species composition in Culicoides biting midges. Med Vet Entomol. Wiley Online Library; 2013;27: 104-112.

63. Clausen PH, Adeyemi I, Bauer B, Breloeer M, Salchow F, Staak C. Host preferences of tsetse (Diptera: Glossinidae) based on bloodmeal identifications. Med Vet Entomol. 1998;12: 169-180.

64. Rugadya M, Kamusiime H. Property Rights Assessment in Amuru District: Supporting Seasonal Migration of Wildlife between Murchison Falls National Park and East Madi Game Researve/Zoka Forest. Kampala: Wild Conservation Society Uganda. Kampala Wild Program Wildl Conserv Soc Uganda. 2010;

65. Sharon Lenia. UWA Officials Move to Control Influx of Elephants from South Sudan [Internet]. 2014 [cited 20 Feb 2020] p. Uganda Radio Network. Available: https://ugandaradionetwork.com/story/uwaofficials-move-to-control-influx-of-elephants-from-south-sudan\#ixzz3oenLNdyG)

66. Okoth JO, Kapaata R. Trypanosome infection rates in Glossina fuscipes fuscipes Newst. in the Busoga sleeping sickness focus, Uganda. Ann Trop Med Parasitol. Taylor \& Francis; 1986;80: 459461.

67. Mohamed-Ahmed MM, Odulaja A. Diel activity patterns and host preferences of Glossina fuscipes fuscipes (Diptera: Glossinidae) along the shores of Lake Victoria, Kenya. Bull Entomol Res. Cambridge University Press; 1997;87: 179-186.

68. Njagu Z, Mihok S, Kokwaro E, Verloo D. Isolation of Trypanosoma brucei from the monitor lizard (Varanus niloticus) in an endemic focus of Rhodesian sleeping sickness in Kenya. Acta Trop. Elsevier; 1999;72: 137-148.

\section{Tables}

\section{Table 1: Expected and obtained band sizes for amplification using nested ITS primers (Adapted from Cox et al., [23])}


Expected band size (bp) from Band sizes (bp) obtained by

\section{Species}

T. congolense (Forest)

T. congolense (Kilifi)

1422

$T$.

congolense (Savannah) 1413

T. congolense (Tsavo) 954

1207-1224

850

611

988
Cox et al., (2005)

1501

1430

1408

951

1215

847

620

998

Table 2: Results of entomological surveys

\begin{tabular}{|c|c|c|c|c|c|c|c|c|c|}
\hline District & Village & $\mathbf{x}$ & $\mathrm{Y}$ & $\begin{array}{l}\text { No of } \\
\text { traps }\end{array}$ & Male & Female & Total & FTD & MWFV \\
\hline \multirow[t]{5}{*}{ Adjumani } & Olwi & 3.149863 & 31.681045 & 10 & 10 & 18 & 28 & 0.93 & 3.8 \\
\hline & Osugo East & 3.200765 & 31.722688 & 10 & 32 & 49 & 81 & 2.70 & 2.8 \\
\hline & Olobo & 3.384375 & 32.011374 & 12 & 55 & 60 & 115 & 3.19 & 4.3 \\
\hline & Oringya & 3.486135 & 32.010335 & 11 & 14 & 21 & 35 & 1.06 & 4.5 \\
\hline & Pagirinya & 3.377809 & 31.994145 & 10 & 29 & 32 & 61 & 2.03 & 3.6 \\
\hline \multirow[t]{5}{*}{ Moyo } & Ori & 3.647330 & 31.789970 & 10 & 10 & 29 & 39 & 1.30 & 4.2 \\
\hline & Orubakulem & 3.691983 & 31.780385 & 13 & 64 & 79 & 143 & 3.67 & 3 \\
\hline & Lea & 3.592517 & 31.606833 & 11 & 30 & 49 & 79 & 2.39 & 2.8 \\
\hline & Cefo & 3.605500 & 31.651733 & 10 & 12 & 8 & 20 & 0.67 & 3.5 \\
\hline & Moyipi & 3.637940 & 31.718250 & 12 & 13 & 8 & 21 & 0.58 & 3 \\
\hline Total & & & & 109 & 269 & 353 & 622 & & \\
\hline
\end{tabular}

*MWFV refers to Mean Wing Fray Value; X and Y refer to the values of X and Y coordinates of the villages 
Table 3: Rate of trypanosome infection in the villages of Moyo and Adjumani districts, northwestern Uganda

\begin{tabular}{|c|c|c|c|c|c|c|c|c|}
\hline District & Village & $\begin{array}{l}\text { Total } \\
\text { examined }\end{array}$ & $\begin{array}{l}\text { Total } \\
\text { infected }\end{array}$ & $\begin{array}{l}\text { Infection } \\
\text { rate (\%) }\end{array}$ & T. vivax & T. brucei & T. simiae & $\begin{array}{l}T \\
\text { Congolense }\end{array}$ \\
\hline \multirow[t]{5}{*}{ Adjumani } & Olwi & 12 & 0 & 0 & 0 & 0 & 0 & 0 \\
\hline & Osugo East & 35 & 4 & 11.42 & 3 & 0 & 0 & 1 \\
\hline & Olobo & 60 & 11 & 18.33 & 7 & 1 & 1 & 2 \\
\hline & Oringya & 14 & 2 & 14.2 & 1 & 0 & 0 & 1 \\
\hline & Pagirinya & 29 & 1 & 3.45 & 1 & 0 & 0 & 0 \\
\hline \multirow[t]{6}{*}{ Мoyo } & Ori & 16 & 1 & 6.25 & 1 & 0 & 0 & 0 \\
\hline & Orubakulem & 60 & 7 & 11.67 & 3 & 1 & 1 & 2 \\
\hline & Lea & 30 & 3 & 10 & 2 & 0 & 0 & 1 \\
\hline & Cefo & 8 & 0 & 0 & 0 & 0 & 0 & 0 \\
\hline & Moyipi & 8 & 0 & 0 & 0 & 0 & 0 & 0 \\
\hline & & & & & 18 & & & \\
\hline Total & & 272 & 29 & 10.67 & $(6.62 \%)$ & $2(0.73 \%)$ & $2(0.73 \%)$ & $7(2.57 \%)$ \\
\hline
\end{tabular}

Table 4: Details of identification and accession numbers for all reference sequences for COI and cytb gene sequences generated 


\begin{tabular}{|c|c|c|c|}
\hline Host species identified & $\begin{array}{l}N \\
(n=30)\end{array}$ & $\begin{array}{l}\text { Closest match } \\
\text { on BLAST - } \\
\text { Genbank ID } \\
\text { (COI) }\end{array}$ & $\begin{array}{l}\text { Closest match on BLAST - } \\
\text { Genbank ID (Cyt b) }\end{array}$ \\
\hline \multirow[t]{4}{*}{ Humans (Homo sapiens) } & 08 & JF739540.1 & AY509658 \\
\hline & & JQ705025.1 & GU123040.1 \\
\hline & & JQ705660.1 & HM036565 \\
\hline & & JQ704657.1 & GU123040.1 \\
\hline \multirow[t]{3}{*}{ Varanus niloticus } & 05 & HQ219067.1 & ND \\
\hline & & AB185327.1 & \\
\hline & & HQ219069.1 & \\
\hline \multirow[t]{4}{*}{ Cattle (Bos taurus) } & 14 & JN817351 & EU365345 \\
\hline & & JN817314 & AY682374 \\
\hline & & JN817330 & EU365345 \\
\hline & & JN817351 & \\
\hline Pelusios chapini & 02 & HQ329729.1 & U81347.1 \\
\hline $\begin{array}{l}\text { African Savanah Elephant } \\
\text { (Loxodonta africana) }\end{array}$ & 01 & AB443879.1 & AY768855 \\
\hline
\end{tabular}

*Data combine both cytb and COI, and GenBank accession numbers for representative sequences given, and where not determined indicated as ND.

\section{Figures}




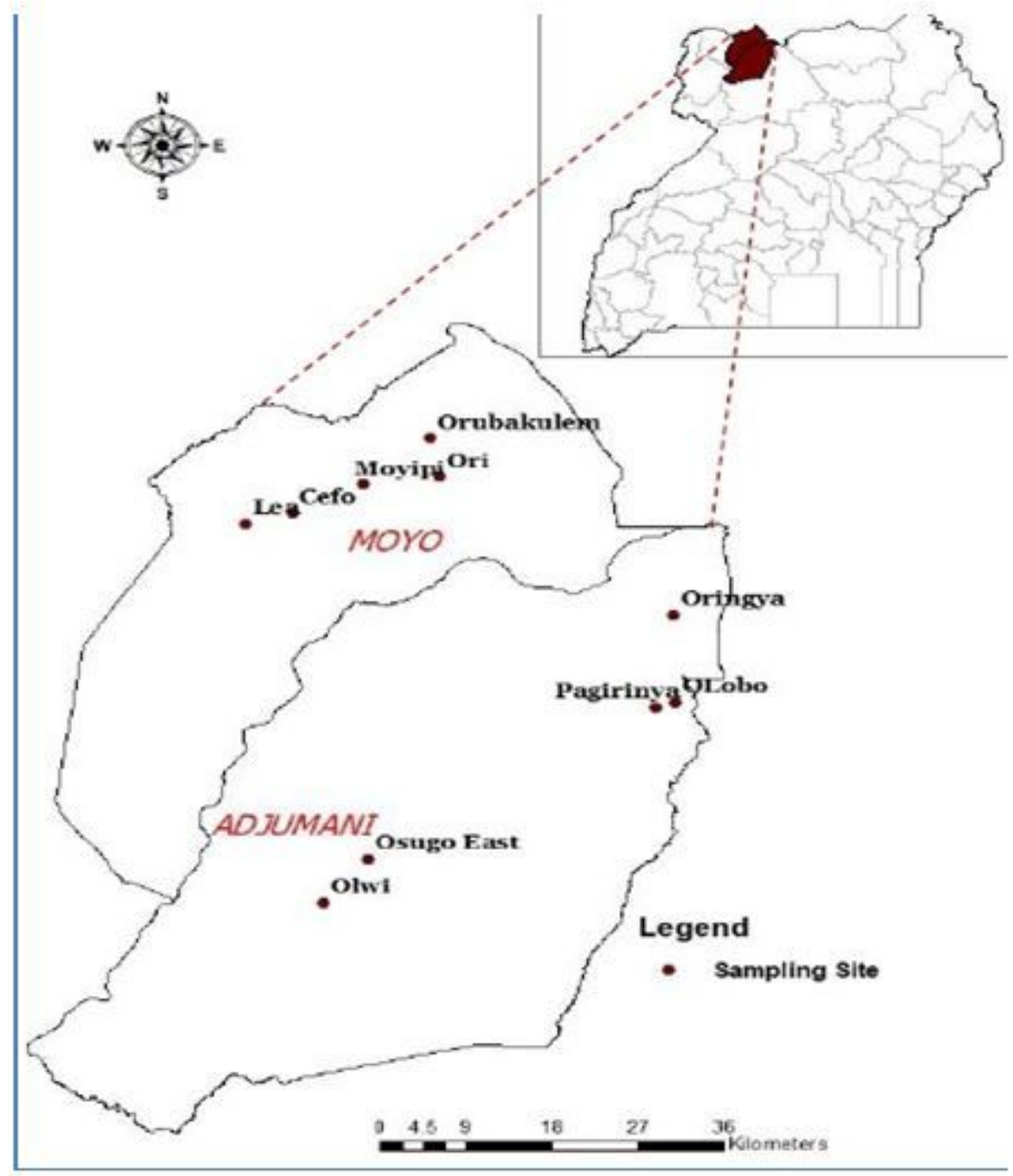

Figure 1

Map of study area showing sampled villages. Map was created by the authors using ArcGIS version 10.3.1. 


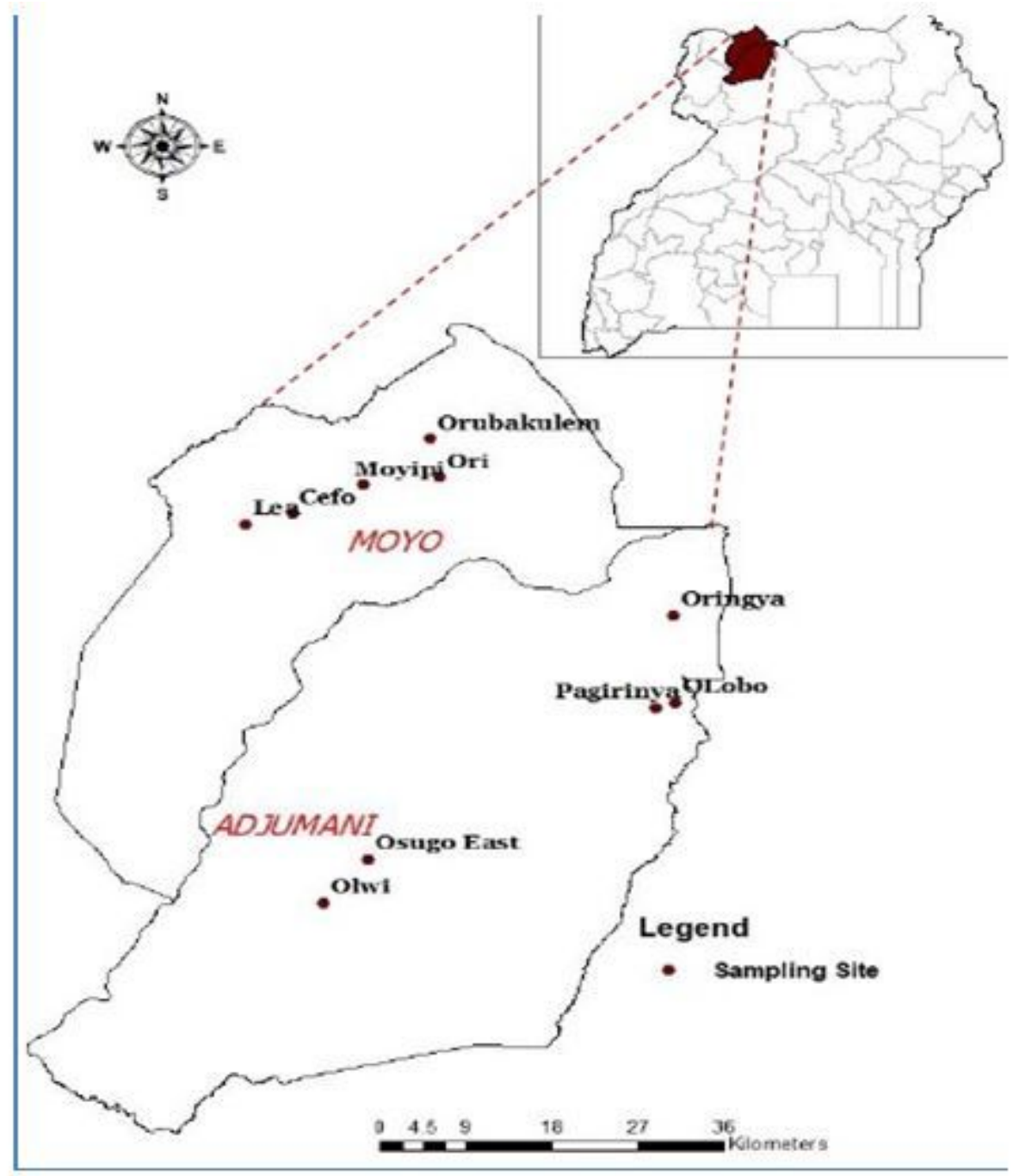

Figure 1

Map of study area showing sampled villages. Map was created by the authors using ArcGIS version 10.3.1. 


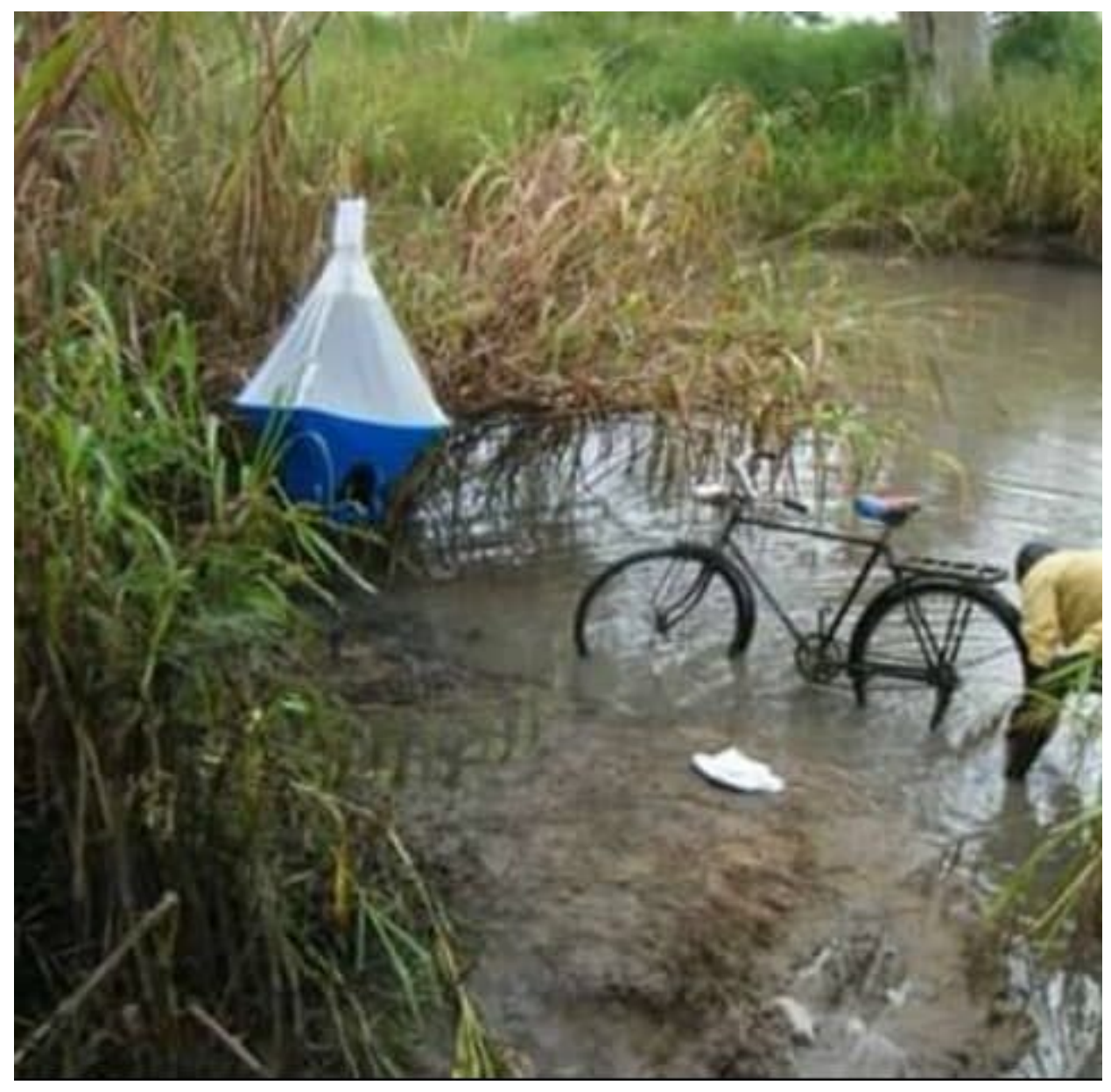

\section{Figure 2}

A biconical trap baited with cow urine and acetone to enhance trapping efficiency deployed along a river in the study area. 


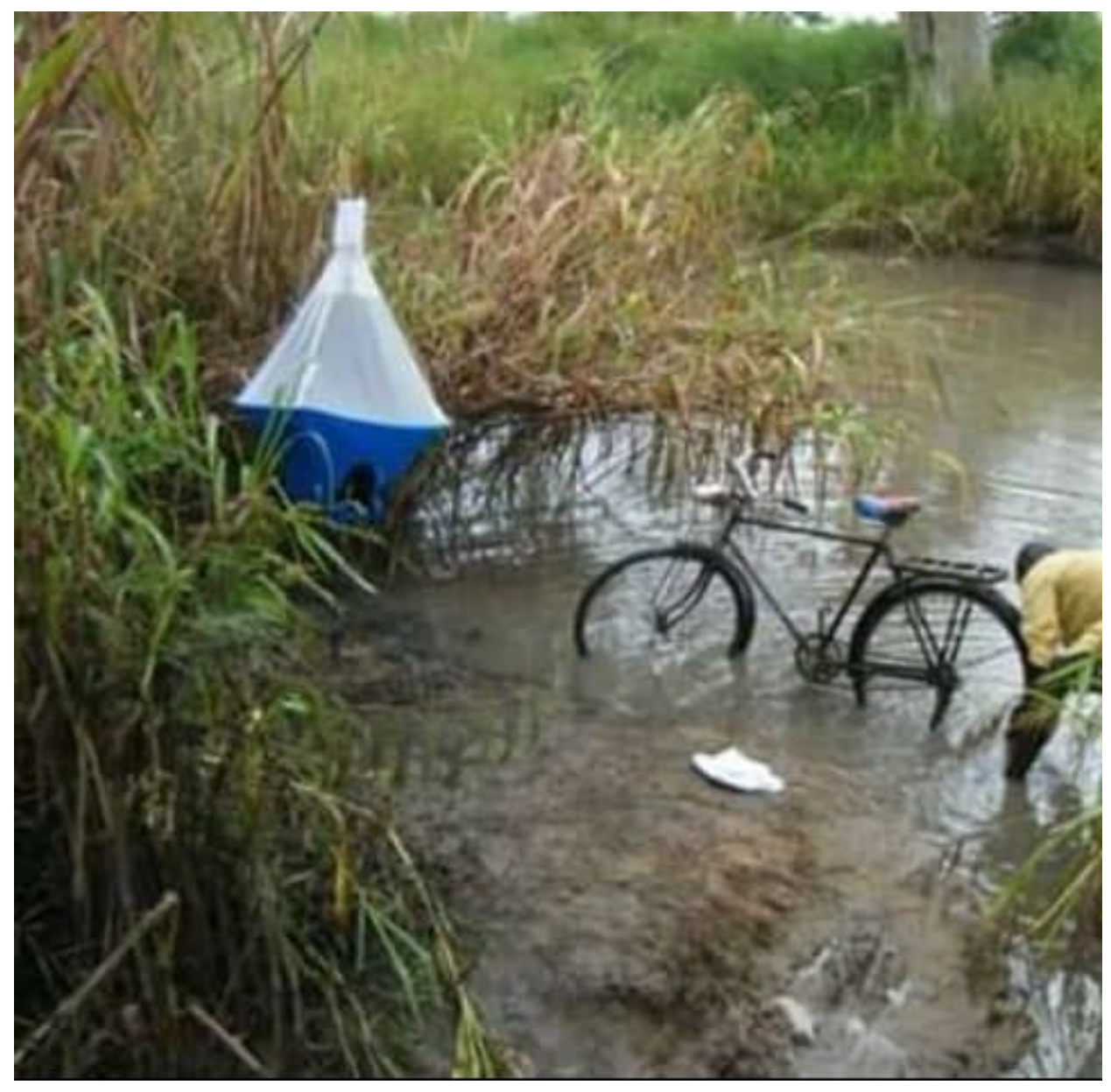

\section{Figure 2}

A biconical trap baited with cow urine and acetone to enhance trapping efficiency deployed along a river in the study area. 


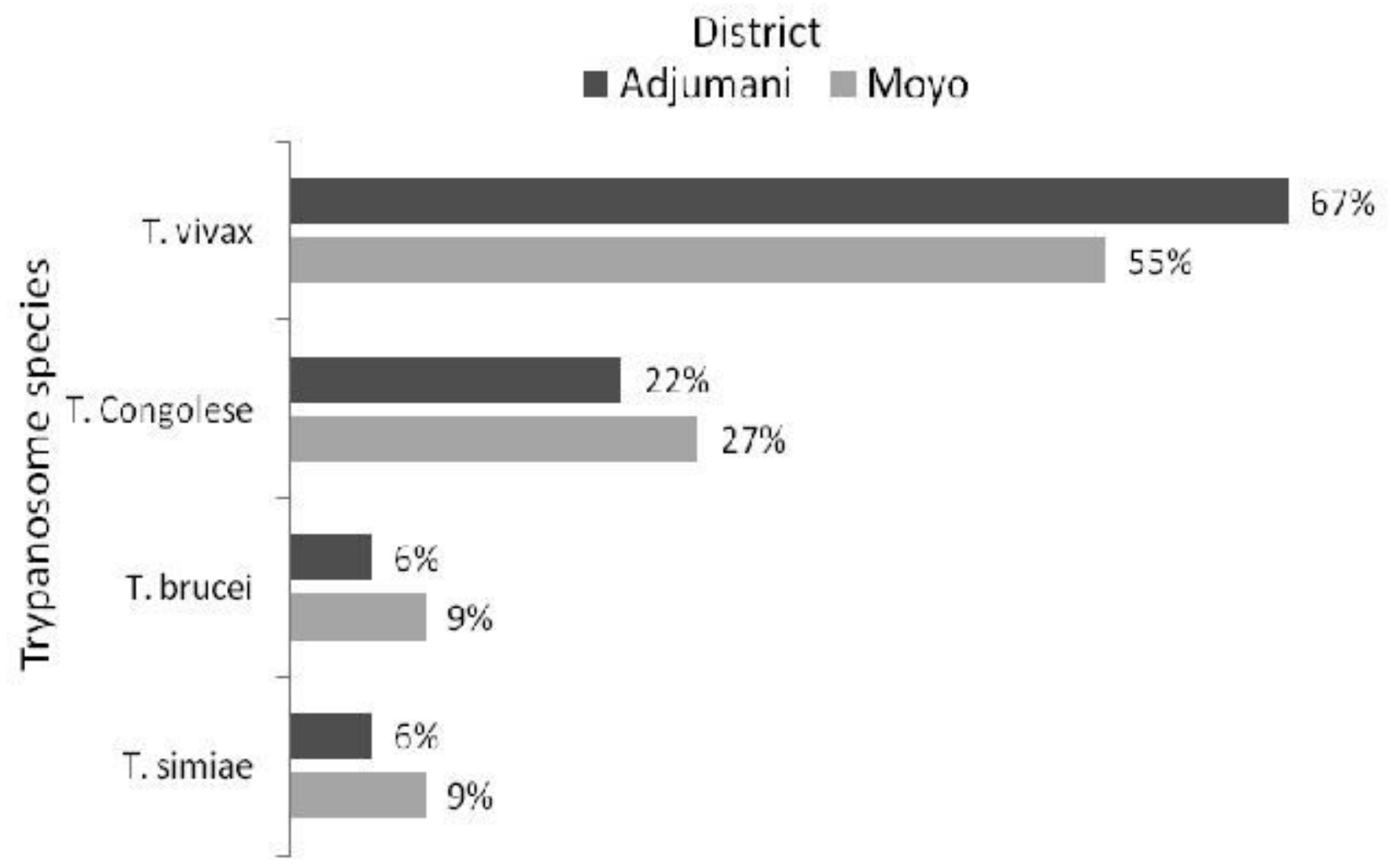

Figure 3

Overall prevalence of the different trypanosome species and subspecies in Moyo and Adjumani Districts, Northwestern Uganda. 


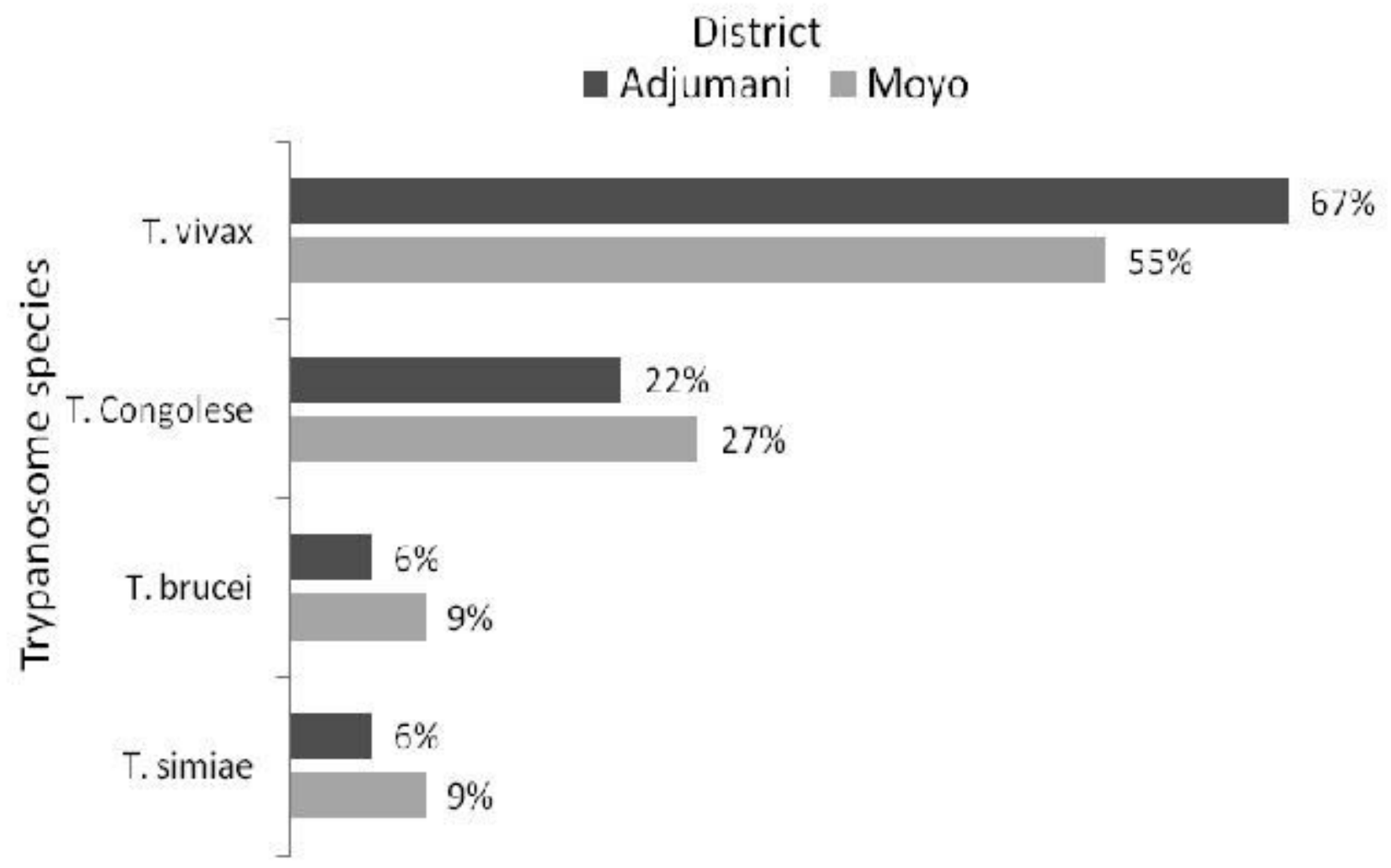

Figure 3

Overall prevalence of the different trypanosome species and subspecies in Moyo and Adjumani Districts, Northwestern Uganda. 

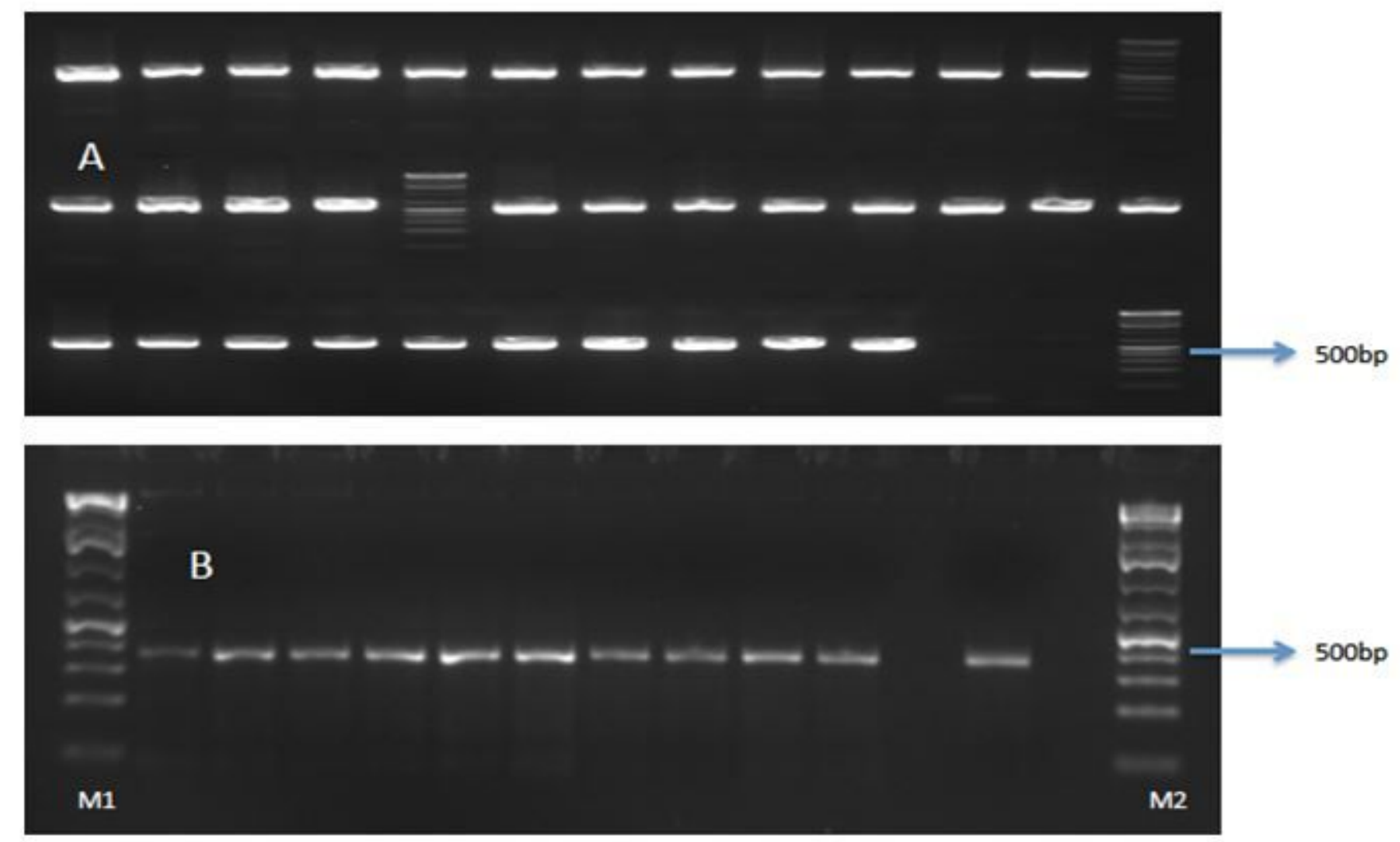

\section{Figure 4}

Representative gel photograph showing 650bp (A) and $359 \mathrm{bp}(\mathrm{B})$ fragments size of COI and cyt b gene amplification products. Lanes M1, M2: 75 bp marker. 

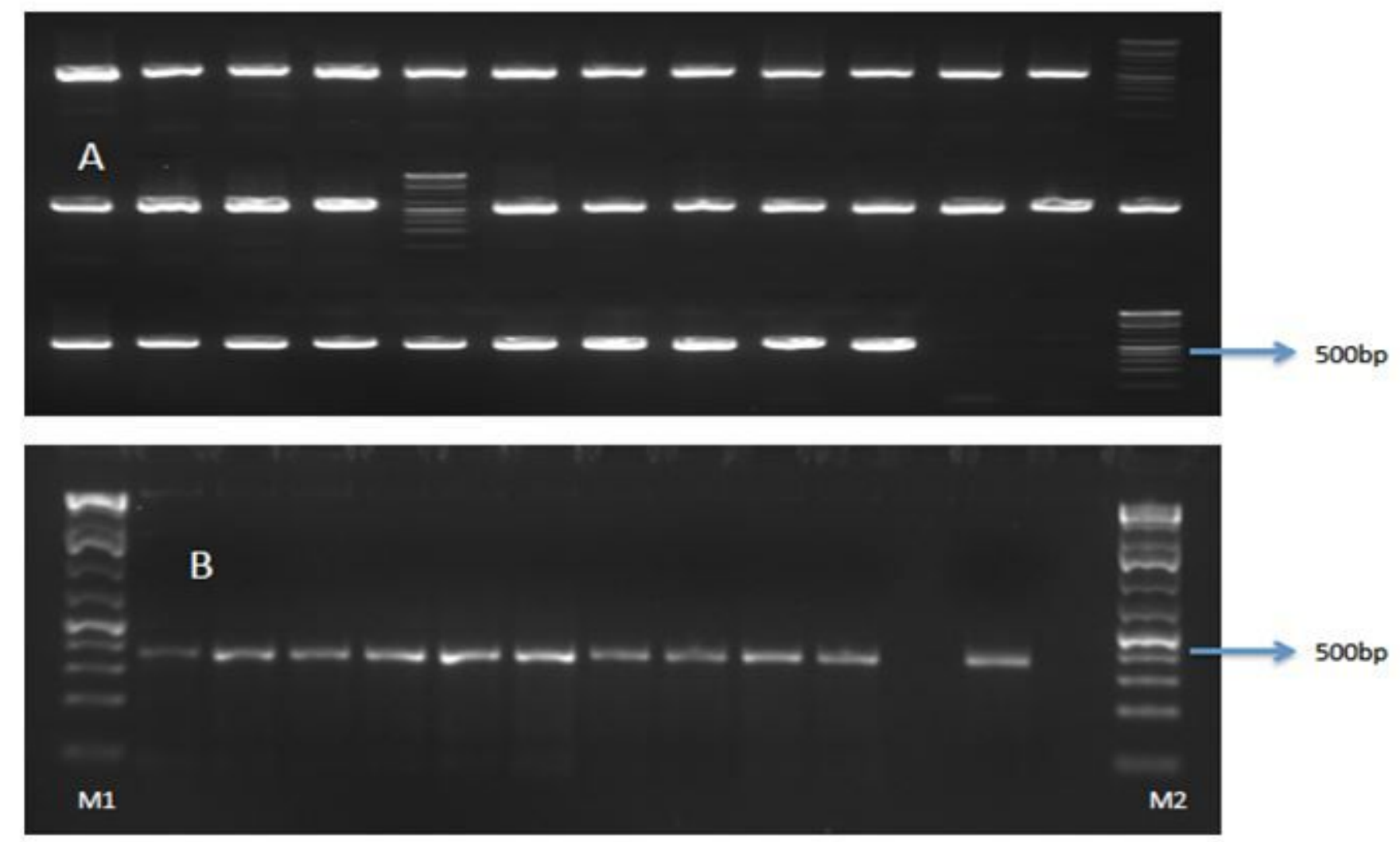

\section{Figure 4}

Representative gel photograph showing 650bp (A) and $359 \mathrm{bp}(\mathrm{B})$ fragments size of COI and cyt b gene amplification products. Lanes M1, M2: 75 bp marker. 